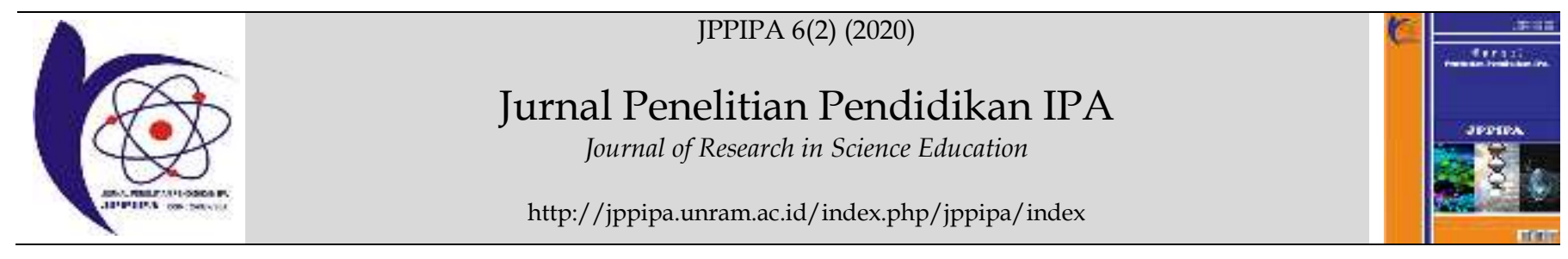

\title{
Curriculum Analysis of Biological Learning Media Module Development Based on Project Based Learning (PjBL)
}

\author{
Diana Susanti ${ }^{*}$, Liza Yulia Sari ${ }^{1}$, Vivi Fitriani ${ }^{1}$ \\ ${ }^{1}$ Department of Biology Education, STKIP PGRI West Sumatra, Indonesia
}

DOI: $10.29303 /$ jppipa.v6i2.302

\section{Article Info}

Received : August 10th 2019

Revised : June $5^{\text {th }}, 2020$

Accepted : June 9th, 2020

\begin{abstract}
Biology Learning Media Course requires students to be able to produce biology learning media. In the previous recovery, students were less creative in producing media for Biology. So students are less able to create suitable media. During this time students do not have the right learning resources in exploring creativity. For this reason, the development of project-based learning-based modules is carried out to provide appropriate learning resources and increase student creativity. The purpose of this study was to determine curriculum analysis for the development of media learning modules based on $\mathrm{PjBL}$. Research is a research development using the $4 \mathrm{D}$ model at a defined stage. Curriculum analysis data were obtained through descriptive analysis. The results showed that 9 materials needed development in the module including communication, learning media, classification of educational media, characteristics of students and their relation to the biology learning media, the role of media in achieving learning objectives, multimedia, photography and video shooting, designing, presenting and displaying, of biology media, media scenarios biology learning. It can be concluded that there are nine materials in developing a learning media module based on PjBL.
\end{abstract}

Keywords: Material Analysis; Modules; Project-Based Learning (PjBL); Media learning of Biology.

Citation: Susanti, D., Sari, L.Z, \& Fitriani, V. (2020). Curriculum Analysis of Biological Learning Media Module Development Based on Project Based Learning (PjBL). Jurnal Penelitian Pendidikan IPA (JPPIPA), 6(2), $157-161$. doi:https://doi.org/10.29303/jppipa.v6i2.302

\section{Introduction}

Biology Education Study Program STKIP PGRI West Sumatra. This course discusses the understanding of the understanding, types, characteristics, and functions of media in general communication and learning biology in particular, as well as determining and designing learning media by the characteristics of the material and learning objectives, operationalize the biology and middle school biology learning media in the classroom biology Learning Media course is one of the compulsory courses in the Biology Education Study Program STKIP PGRI West Sumatra. This course discusses the understanding of the understanding, types, characteristics, and functions of media in general communication and learning biology in particular, as well as determining and designing learning media by the characteristics of the material and learning objectives, operationalize the biology and middle school biology learning media in the classroom. it is studied to improve the quality of learning, improve efficiency and effectiveness of students in creating media for teaching junior and senior high school biology. On the other hand, this lecture provides provisions for students to learn to build biology learning media by utilizing various types of media and IT advancements, such as original media, durability, graphics, graphics, models, and computer-based media. 
Based on the results of interviews conducted by the author with lecturers who teach biology learning media, information is obtained that the lecture process takes place using lecture, discussion, and question and answer methods. Lecturers have not used the learning model, and in this course, students have difficulty in the understanding of lecture material. This is due to one of them by lecture material at each meeting in general do not have the stages or steps of work students are expected to be able to explain in general the concepts of communication and media of learning biology, analyze various types of media in learning biology, understand the understanding, types, characteristics and functions media in communication in general and biology learning in particular, and are able to determine instructional media in accordance with the characteristics of the material and learning objectives, determine instructional media that are appropriate to the characteristics of middle and high school students, design biology learning media based on junior and high school curriculum, present biology learning media based on the junior and senior high school curriculum that has been designed and operationalized the middle and high school biology learning media in the classroom So in this course students are required to be able or able to meet the objectives of this course.

Another condition found is the lack of student creativity in lectures is the unavailability of teaching materials that support them in understanding the concept of learning media and designing/creating various types of media. Lack of student understanding in understanding the concepts and materials that have been given by lecturers because students only rely on teaching materials in the form of power points to be read during lectures without the help of other teaching materials. The teaching materials used by lecturers have only helped the understanding of concepts from various media, not in designing/creating creative media that is used in learning as a result in making media, they are less skilled and the value of skills in creating media is low.

For this reason, a module was developed as teaching material for students and lecturers to help create student understanding and creativity. The module is an independent learning package that includes a series of planned learning experiences and is systematically designed to help students achieve their learning goals (Prastowo, 2011). By the opinion of Budiono and Susanto (2006) states that modules are arranged systematically with components including loading student activity sheets, worksheets, student worksheet keys, question sheets, and answer keys for question sheets. Thus the modules developed are oriented to the project-based learning model.
Project-Based Learning (PjBL) is a learning model that organizes classes in a project (Thomas, 2002). This PjBL makes projects that require students to, solve real problems and issues that have an interest in others, are actively involved in their learning, and choose important things during the project, showing clearly that they have learned concepts keys and skills (Addin, 2014). The existence of this PjBl Model is expected to increase student learning motivation, increase the ability and creativity of students to create projects (biology learning media), enhance collaboration or the role of group collaboration, and develop the ability to plan.

Preliminary research by looking at the needs analysis of project-based learning module based learning media has been carried out and the results of the analysis of the needs of lecturers and students on the development of PjBL-based modules are in the criteria needed with the percentage of $66.67 \%$ and $76.25 \%$ Susanti et al, 2019). For this reason, it is continued with curriculum analysis in biology learning media courses for the development of biology-based learning media modules based on project-based learning. Thus proceed to the curriculum analysis of the development of project-based learning module based learning media. This study aims to determine curriculum analysis for the development of biology learning media modules based on Project Based Learning.

\section{Method}

Based on the problems studied, the type of research used is development research (development research). According to Komalasari et al (2019), this research is a method for producing certain products and testing the effectiveness of these products. The research model used in this study is four-D models. The development of Four-D models consists of 4 main stages: define (determine the material), design (develop), develop (develop), and disseminate (deployment) (Trianto, 2009). The Development Procedure in this study is only at the define stage, which aims to determine the basic problems needed in developing biology learning media so that it can be an appropriate alternative learning media. Namely one of them by doing curriculum analysis. The data obtained in the form of descriptive data that illustrates the results of curriculum analysis of biology learning media courses on the development of biology-based learning media module project-based learning. This analysis is seen from several components in the curriculum of biology learning media courses contained in the Learning Implementation Plan, namely the learning outcomes of study program 
graduates and course learning outcomes. Then the data were analyzed descriptively.

\section{Result and Discussion}

The results of the analysis of the biology learning media curriculum seen from the learning outcomes of study program graduates and course learning outcomes found that in this course there were several learning achievements, including, attainment of learning attitudes, general skills, special skills, and knowledge. Learning outcomes for the expected attitude, namely, students are able to show good morals and ethics in each lecture meeting that is undertaken, are able to show an attitude of respecting the opinions of others in conducting lectures, able to show an attitude of cooperation and have a care for others. In each group activity that is given, able to show a disciplined attitude towards the given task, able to show a responsible attitude for the task given independently. With the existence of biology learning media courses, students are expected to be able to make various innovations in carrying out biology learning with various approaches, strategies, methods, media and learning techniques based on the National Education Standards by utilizing science and technology so that students are able to achieve educational goals and implement them according to the occupational fields occupied in his life.

Learning achievement for general skills, namely students are expected to be able to have logical, critical, systematic, innovative thinking on the tasks given, students are able to show independent, quality and measurable performance in discussing and doing assigned tasks, students are responsible for the achievement of group work and assignments are given, students are able to choose and design biology learning media used in learning according to the curriculum, students are able to communicate effectively, empathically and politely with fellow and lecturers.

Learning outcomes for special skills that students are expected to be able to apply mastery of biological concepts and education in evaluating biology learning processes and outcomes systematically and continuously by utilizing the development of science and technology and in accordance with National Education Standards, problems in class and school, student development and its environmental characteristics so as to produce meaningful data and information in decision making, able to analyze secondary school biology curriculum through curriculum study activities so as to produce indicators, teaching materials, assessment instruments, strategies, and learning media in accordance with the applicable curriculum, able to apply the concepts of biology and technology education in developing learning products and biological products by utilizing the progress of science and technology to support the implementation of biological learning, and the preservation of biodiversity and the environment.

From the learning achievements above, the development of the nine material on biology learning media courses is including communication, learning media, classification of educational media, characteristics of students and their relation to the biology learning media, the role of media in achieving learning objectives, multimedia, photography and video shooting, designing, presenting and displaying, of biology media, media scenarios biology learning. In the communication material, which discusses the understanding, process, error, and form of communication. This was discussed in order to avoid mistakes in communication. And communication actually requires the media to be easily understood and understood. For learning media material described into Understanding Media, Functions, and Characteristics of Learning Media and Media Selection. This material will be in line with the classification of educational media that discusses the Classification of Educational Media and Types of Educational Media. In this material linkages with project-based learning are needed, because students begin to study and find their biology media that is suitable for application in junior/senior high schools through projects provided by lecturers with good communication. Because with project-based learning students can use the media as a means of communication and be used in the learning process through the execution of the project. In line with Rezeki et al (2015) Project-based learning is a learning method that can help students build their thinking and communication skills.

On the material characteristics of junior and senior high school students and their relation to biology learning media, the characteristics of students in general, the characteristics of junior high school students, and the characteristics of senior high school students will be discussed. Followed by a discussion of the role of the media in achieving learning objectives including learning media selection and learning media selection steps. These two materials are very important in determining student creativity because this material looks at the relationship of the media with the character of students and their relationship in achieving learning objectives. This is certainly related to the benefits and functions of learning media in achieving student material in the learning. Tofanao (2018) explains that the use of media by teachers in the classroom and outside the classroom will achieve learning objectives. Learning media is also not just a complement to teachers to greet information to students, but can be a 
requirement in the achievement of users for maximum learning (Mahnun. 2012). The media is also a tool or medium as an intermediary to deliver learning materials from teachers to students (Karo-karo et al. 2018).

Multimedia material discusses the notion of multimedia, multimedia hardware, and multimedia software. Followed by Photography and Video Shooting material which is detailed into photography and video. In this material, instructional media are adapted to technological developments and times. Learning technology will continue to develop along with the times (Rahmayanti, 2015). It is different from the material designing and presenting and displaying biology/middle school biology learning media because these material students are asked to make media based on selected learning objectives. Finally, the biology learning media scenario material discusses the scenarios created by students and how to make these scenarios. On these four materials, students have started making media in all aspects including multimedia and displaying the media like a teacher teaching in class. The media designed must of course be appropriate and true to the material so that the media can assist the teacher in teaching. Learning media can be a vehicle for channeling messages and learning information. Well-designed learning media will greatly assist students in digesting and understanding the subject matter (Muhson, 2010). And also learning media can help teachers to make it easier to deliver the subject matter to students so as to facilitate the achievement of learning objectives (Adam et al, 2015).

Judging from the problems, almost all lecture material on biology learning media courses does not contain work steps. It's just that it contains material, so students have difficulty understanding the material and the lack of student creativity in lectures is the unavailability of teaching materials that support them in understanding the concept of instructional media and designing/creating various types of media. Lack of student understanding in understanding the concepts and materials that have been given by lecturers because students only rely on teaching materials in the form of power points to be read during lectures without the help of other teaching materials.

In lectures on biology learning media, students are expected to be able to design biology learning media that are adapted to junior or senior high school levels that can later be used in the learning process. In addition to designing biology learning media, students are also expected to be able to design Learning Implementation Plans (RPP) that are tailored to junior or senior high school level material, so that lecture material is relevant to the application of lecture material later in the field. Susilo Research Results (2014) states that overall the findings of material based on local potential in the Bantul district area are by the needs of junior high school bio-teaching materials and meet the principles of relevance or suitability. Able to apply mastery of biological concepts in designing biology learning by utilizing science and technology and by National Education Standards, problems in the classroom, and schools, student development, and environmental character to produce learning designs that encourage active participation and develop the potential of each student.

In the learning process, it is very much needed to learn media or teaching materials, so that it can help students in lectures. As expressed by (Cikarge, et al 2018) that learning media is an important component in the learning process. The presence of learning media will facilitate educators in delivering material and increase understanding of the material and the formation of students' skills so that students are easy to learn.

\section{Conclusion}

From the results of this research, it can be concluded that several learning achievements must be achieved, namely attainment learning attainment, general skills learning achievement, special skills learning achievement and knowledge learning achievement, and some material that will be included in the module between them communication, learning media, classification of educational media, characteristics of students and their relation to the biology learning media, the role of media in achieving learning objectives, multimedia, photography and video shooting, designing, presenting and displaying, of biology media, media scenarios biology learning

\section{Acknowledgments}

Thank you to DRPM DIKTI and STKIP PGRI West Sumatra for funding and facilitating this research.

\section{References}

Adam, S. (2015). Pemanfaatan Media Pembelajaran Berbasis Teknologi Informasi Bagi Siswa Kelas X Sma Ananda Batam. Computer Based Information System Journal, 3(2). Retrieved from http://ejournal.upbatam.ac.id/index.php/cbis/ar ticle/view/400.

Addiin, I., Redjeki, T., \& Ariani, S.R.D. (2014). Penerapan Model Pembelajaran Project Based Learning (Pjbl) Pada Materi Pokok Larutan Asam dan Basa di Kelas XI IPA 1 SMA Negeri 2 Karanganyar Tahun Ajaran 2013/2014. Jurnal 
Pendidikan Kimia (JPK) Universitas Sebelas Maret. 3(4), 7-16.

Budiono, \& Santoso. (2006). Penyusunan dan Penggunaan Modul Pembelajaran Berdasar Kurikulum Berbasis Kompetensi Sub Pokok Bahasan Analisa Kuantitatif Untuk Soal-Soal Dinamika Sederhana Pada Kelas X Semester I SMA. Jurnal Pend. Fisika Indonesia. 4(2), 79-87. doi: https://doi.org/10.15294/jpfi.v4i2.166

Cikarge, G.P., \& Utami, P. (2018). Analisis dan Desain Media Pembelajaran Praktik Teknik Digital Sesuai RPS. Jurnal Elinvo. 3 (1), 92-105. doi: https:// doi.org/10.21831/elinvo.v3i1.20509

Karo-karo. I. R., dan Rohani. (2018). Manfaat media dalam pembelajaran. Jurnal AXIOM: VII(1), 91-96. doi: http://dx.doi.org/10.3082/axiom.v7i1.1778

Komalasari, B., Jufri, A., \& Santoso, D. (2019). Pengembangan Bahan Ajar IPA Berbasis Inkuiri Terbimbing untuk Meningkatkan Literasi Sains. Jurnal Penelitian Pendidikan IPA, 5(2), 219-227. doi:https:// doi.org/10.29303/jppipa.v5i2.279

Mahnun, N. (2012). Media Pembelajaran (Kajian terhadap Langkah-langkah Pemilihan Media dan Implementasinya dalam Pembelajaran). Jurnal Pemikiran Islam, 37(1), 27-33.

Muhson, A. (2010). Pengembangan Media Pembelajaran Berbasis Teknologi Informasi. Jurnal Pendidikan Akuntansi Indonesia, VIII(2), 1-10. doi: https://doi.org/10.21831/jpai.v8i2.949

Prastowo, A. (2011). Panduan Kreatif Mebuat Bahan Ajar Inovatif. Jogjakarta: Diva Press.

Rahmayanti. (2015). Penggunaan Media It Dalam Pembelajaran. jurnal Ilmiah CIRCUIT. 1(1). 85-97. doi: http://dx.doi.org/10.22373/crc.v1i1.313

Rezeki, R.D., Nurhayati, N.D., dan Mulyani, S. (2015). Penerapan Metode Pembelajaran Project Based Learning (PJBL) Disertai dengan Peta Konsep Untuk Meningkatkan Prestasi dan Aktivitas Belajar Siswa Pada Materi Redoks Kelas X-3 SMA Negeri Kebakkramat Tahun Pelajaran 2013/2014. Jurnal Pendidikan Kimia (JPK), 4(1). 74-81

Susanti, D., Sari, 1. Y., dan Fitriani, V. (2019). Need Analysis of Biology Modul as Learning Media Based on Project Based-Learning. Education Journal, 8(4): 134-137. doi: 10.11648/j.edu.20190804.11

Susilo, M. J. (2014). Analisis Potensi Materi Ajar Biologi SMP Berbasis Pada Potensi Lokal Dari Area Sungai Gajah: Jurnal Bioedukatika, 2(1), 1-9. DOI: http://dx.doi.org/10.26555/bioedukatika.v2i1.41 $\underline{03}$

Thomas, J. W. (2000). A Review of Research on Project Based Learning. California: The Autodesk Foundation.
Tofanao, T. (2018). The role of instructional media to improving student interest. Jurnal Komunikasi Pendidikan, 2(2), 103-114.

Trianto. (2009). Mendesain Model Pembelajaran InovatifProgresi. Jakarta: Kencana. 